\title{
Impact of the alien plant Impatiens glandulifera on species diversity of invaded vegetation in the northern foothills of the Tatra Mountains, Central Europe
}

\author{
Piotr Kiettyk (D) Anna Delimat
}

Received: 12 June 2018/ Accepted: 18 November 2018/Published online: 22 November 2018

(C) The Author(s) 2018

\begin{abstract}
The impact of exotic annual Impatiens glandulifera on invaded European vegetation is ambiguous; there are studies reporting considerable negative as well as weak or even no impact of this invader on species richness and diversity of the invaded communities. The effect of invasion by $I$. glandulifera on species richness, diversity and the composition of resident vegetation was studied in the northern foothills of the Tatra Mountains in southern Poland. Two approaches were used: comparing diversity measures of the invaded and uninvaded plots and analysing changes in species richness and diversity in plots grouped according to increasing cover percentage of I. glandulifera. Invaded plots harboured 0.27 fewer species per $4 \mathrm{~m}^{2}$ and had significantly reduced values of the Shannon and Simpson diversity indices
\end{abstract}

Communicated by Katinka Ruthrof.

Electronic supplementary material The online version of this article (https://doi.org/10.1007/s11258-018-0898-z) contains supplementary material, which is available to authorized users.

\section{P. Kiełtyk $(\bowtie)$}

Faculty of Biology and Environmental Sciences, Cardinal Stefan Wyszyński University in Warsaw, Wóycickiego 1/3, 01-938 Warsaw, Poland

e-mail: kieltyk@wp.pl

\section{A. Delimat}

W. Szafer Institute of Botany, Polish Academy of

Sciences, Lubicz 46, 31-512 Kraków, Poland and Pielou's measure of evenness. Analysis of changes in diversity measures with the increase in $I$. glandulifera cover revealed that an increase in $I$. glandulifera cover was from the onset related to a decrease in the diversity of the invaded plant communities, but after exceeding a $80 \%$ cover, this species dramatically reduced the diversity of the invaded vegetation. Non-metric multidimensional scaling analysis indicated a significant shift in the composition of invaded plots in relation to uninvaded plots, which resulted from the proportional increase in the more shade tolerant and nutrients demanding species. Our results suggest that in species-rich vegetation, such as fresh meadows and related communities, I. glandulifera may suppress weak competitors and, thus, negatively impact plant diversity.

Keywords Annual exotic plant · Himalayan Balsam · Invasive species $\cdot$ Plant invasions $\cdot$ Species richness

\section{Introduction}

Invasive species are considered to be the most important drivers of biodiversity decline and adverse changes to ecosystems (Parker et al. 1999; Mack et al. 2000; Gurevitch and Padilla 2004; Vilà et al. 2006). Alien plant invasions are often reported to have a 
detrimental impact on the diversity and species composition of native plant communities (e.g. Levine et al. 2003; Hejda et al. 2009; Kiełtyk 2014; Lazzaro et al. 2015; Hejda et al. 2017); however, the effect of invasive plants on the invaded vegetation varies greatly depending on the characteristics of the invaders and community invasibility (Pyšek and Pyšek 1995; Sakai et al. 2001; Richardson and Pyšek 2006; Hejda 2013; Fried et al. 2014). Invasive alien plants can displace or considerably suppress native plants through superior competitiveness (e.g. BottollierCurtet et al. 2013; Gruntman et al. 2014; Čuda et al. 2015), allelopathy (Ruckli et al. 2014; Loydi et al. 2015), altering ecosystem processes, such as soilnutrient cycling and water fluxes, or disturbance regimes (Levine et al. 2003; Gaertner et al. 2014). In particular, invading species capable of forming dense populations can have a profound effect on native species diversity at the community level and reduce species diversity at higher levels (Hejda et al. 2009).

One of the most highly invasive alien plant species in Europe forming dense populations is the Himalayan Balsam (Impatiens glandulifera Royle, Balsaminaceae), the tallest European herbaceous annual (Beerling and Perrins 1993). I. glandulifera is a species competitively superior to many native and exotic species in Europe (Bottollier-Curtet et al. 2013; Gruntman et al. 2014; Čuda et al. 2015). Its highly competitive ability can be attributed to a number of characteristics: rapid shoot extension and leaf expansion (Clements et al. 2008), attaining a height of $2.5 \mathrm{~m}$ under favourable conditions (Beerling and Perrins 1993) and a substantial height even at low irradiance (Andrews et al. 2009), ability to set dense stands and grow through the entire vegetation period, high propagule pressure lasting until the first frost, and possible allelopathic effects on co-occurring species (Bottollier-Curtet et al. 2013; Gruntman et al. 2014; Čuda et al. 2015). Even though many studies investigated the biology and performance of this species (e.g. Perrins et al. 1993; Bottollier-Curtet et al. 2013; Gruntman et al. 2014; Kostrakiewicz-Gierałt and Zając 2014; Tanner et al. 2014, Čuda et al. 2015), only a limited number of studies were carried out to quantify the potential impact which the invader may have on native vegetation. Moreover, the results of studies on the impact of I. glandulifera on plant diversity are ambiguous, and possible consequences of the invasion by this species for European native plant communities are not clear. For example, Hulme and Bremner (2006) found, in northeast England, a very negative impact of $I$. glandulifera on a riparian community and a reduction in species richness by as much as $25 \%$ due to extensive I. glandulifera stands. Also, Rusterholz et al. (2017), based on their field experiment with removing the invader in northern Switzerland, have recently reported the negative effects of I. glandulifera on the vegetation of the deciduous forest; they found a considerable reduction in plant species richness in both the above-ground vegetation and soil seed bank by $25 \%$ and $30 \%$, respectively. However, as they concluded, the negative effects of the invader only become visible after the passage of several years (Rusterholz et al. 2017). Contrary to the above-mentioned studies, there are results of some studies in which no impact of $I$. glandulifera on resident vegetation or plant diversity was detected. For example, Künzi et al. (2015) found, in different lowland habitats in Switzerland, no effect of I. glandulifera cover on species richness, Shannon diversity and evenness of invaded communities. Similarly, Čuda et al. (2017b) did not detect any impact of I. glandulifera on species richness and diversity in a managed mixed forest in central Bohemia. There are also studies in which only a slight effect of I. glandulifera on species diversity was revealed. For example, Hejda and Pyšek (2006) found, in riparian vegetation in the Czech Republic, that only one measure of species diversity, namely evenness, was significantly different between the invaded and uninvaded vegetation. Also, Hejda et al. (2009) reported no impact of I. glandulifera on species richness and a low impact on species diversity and evenness in native vegetation in various regions of the Czech Republic. Moreover, Diekmann et al. (2016), in various habitats in the lowlands of northwestern Germany found that invasion by I. glandulifera did not cause a considerable negative change in plant species richness and composition; however, they reported a significant decrease in species richness, Shannon diversity and evenness for the invaded vegetation (Diekmann et al. 2016).

This study was carried out in the foothills of the Tatra Mountains, which is a highly valued area protected as a transboundary Polish-Slovak biosphere reserve. Mountain ecosystems are generally less invaded than surrounding lowland ecosystems; however, an increased invasion risk and management 
challenge may be expected in the near future due to climate and land use change (Dainese et al. 2014). The invasion of $I$. glandulifera is often considered a conservation problem in European lowland habitats (e.g. Hejda and Pyšek 2006); however, to our best knowledge, there are no studies assessing the plant's impact on species richness and diversity in invaded species-rich sub-mountain vegetation. In this study, we sought to determine the effect of invasion by $I$. glandulifera on species richness, diversity and composition of invaded vegetation in the lower montane belt in the foothills of the Tatra Mountains. To achieve this, we adopted two different approaches. First, we applied the space-for-time substitution design (e.g. Hejda and Pyšek 2006; Diekmann et al. 2016) in which we compared vegetation characteristics of invaded plots with uninvaded control plots, which were spatially close and environmentally similar and which were supposed to represent vegetation before the invasion event. The second approach was based on the analysis of changes in species richness and diversity in plots grouped in intervals according to increasing cover percentage of I. glandulifera. Both of these approaches must be carefully interpreted considering their possible limitations, but, as pointed out by Hejda and Pyšek (2006), studying the community level impact in situ is desirable as it can provide, by identifying the potential effects of an invading alien, valuable information for landscape management and nature conservation. In this paper, we asked, in particular, the following questions: (1) Do I. glandulifera-dominated stands significantly impact species richness, diversity, evenness and composition of invaded vegetation? (2) What is the relationship between an increasing invader cover and the diversity of plant communities? And (3) which native species are most affected by the invader dominance?

\section{Materials and methods}

Study species and area

The Himalayan Balsam (Impatiens glandulifera Royle, Balsaminaceae) is native to the western Himalaya, where it occurs in wet, open places in deciduous and mixed forests, forest fringes, shrubs and high elevation meadows, most often at elevations ranging from 1800 to $3200 \mathrm{~m}$ a.s.l. (Sharma and
Jamwal 1988; Beerling and Perrins 1993; Pyšek and Prach 1995; Hejda 2009), but it also has been reported at elevations of up to 4000-4300 m a.s.l. (Polunin and Stainton 1984; Adamowski 2008). It was first introduced into Europe in the middle of the nineteenth century as a garden ornamental, and, after some decades, it became naturalized and invasive in most European countries (Beerling and Perrins 1993; Weber 2003; Hejda 2009). In Poland, I. glandulifera was recorded for the first time in 1890 in the southwestern part of the country (Lower Silesia) (TokarskaGuzik 2005), and, within decades, it became common in southern Poland and other parts of the country, with exception of the northeast part of the country, where the species has had only a few recorded stations (Zajacc and Zając 2001). Over the last decades, I. glandulifera became one of the most widespread invasive plants in central Europe (Pyšek and Prach 1995; Wagner et al. 2017). The long-term spread rate of I. glandulifera in the Czech Republic from 1934 to 1995 was estimated to be $3.66 \mathrm{~km}$ per year, which put this species in fourth place of the fastest spreading species out of 50 nonnative naturalized or invasive central European plants (Williamson et al. 2005). The species has spread to many riparian habitats; it often attains dominance in the nitrophilous herbaceous fringes of lowland rivers, but also finds optimum conditions on loamy and sandy riverbanks and in riverine reed vegetation (Pyšek et al. 2012; Čuda et al. 2014). In the last decades, I. glandulifera has broadened its ecological niche (Čuda et al. 2017a) and has increasingly invaded habitats far from river corridors, such as moist forests, forest clearings and edges, wet meadows, alongside roads and railway margins, in ditches and on ruderal ecotopes (Protopopova et al. 2015; Čuda et al. 2017a; Rusterholz et al. 2017).

The study was conducted in the northern foothills of the Tatra Mountains, Tatra County, in southern Poland, in the vertical zone of the lower montane vegetation belt (Fig. 1). Climatic conditions for this area, measured in the town of Zakopane (844 $\mathrm{m}$ a.s.1.), are characterized by the following: a mean annual temperature of $+4.9^{\circ} \mathrm{C}$, a mean temperature of $+14.8{ }^{\circ} \mathrm{C}$ in July (warmest month), a mean temperature of $-5.8^{\circ} \mathrm{C}$ in January (coldest month), the length of the period having an average daily temperature above $+5{ }^{\circ} \mathrm{C}$ being 184 days, the length of the period having an average daily temperature above 


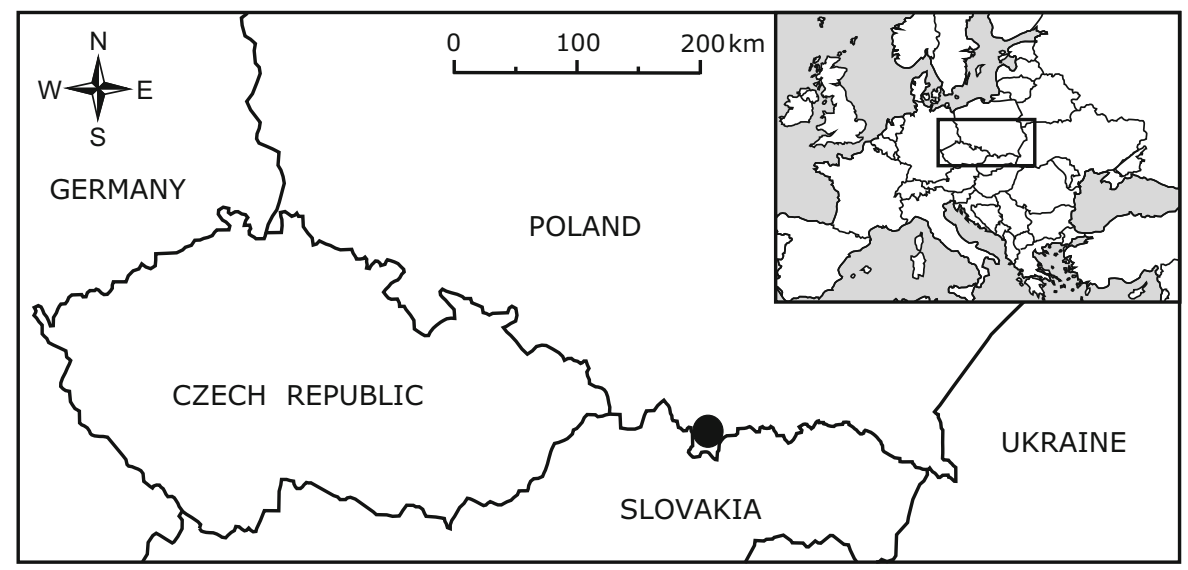

Fig. 1 Location of the study area in the northern sub-Tatra Mountain region, southern Poland

$+10{ }^{\circ} \mathrm{C}$ being 123 days and the mean annual precipitation being $1136 \mathrm{~mm}$ (Kłapowa 1993).

Vegetation sampling

Field work was carried out in late summer, in August and September 2014, when I. glandulifera plants were fully developed. Stands of the invader were found by actively searching suitable areas. At these sites, we examined 65 vegetation plots with I. glandulifera of $4 \mathrm{~m}^{2}$ and 65 control plots of the same dimension. Plots with I. glandulifera were selected to cover a gradient from very low (minimum 10\%) to very high cover of the invader and to represent the different types of habitat and spatial distribution of the species within the study area (see Supplementary Table 1 for site coordinates). Control plots were located spatially very close to the paired plots with I. glandulifera; most often they were adjacent, or within distance of $2 \mathrm{~m}$, with highly similar habitat conditions. The cover of the invader in the control plot was allowed to be at a maximum of $1 \%$. Plots with I. glandulifera were found and sampled mainly in tall herbaceous vegetation of fresh meadows and in adjacent meadows-like road embankments, both vegetation types related to the Molinio-Arrhenatheretea class and, less often, at forest edges. Examined plots were distributed at elevations ranging from $760 \mathrm{~m}$ to $1097 \mathrm{~m}$ a.s.1. (median $885 \mathrm{~m}$ a.s.l., interquartile range 860-940 m a.s.l.).

Species composition was surveyed for each plot, and phytosociological relevés were made using Braun-Blanquet's method and a six-point plant cover scale (Kent 2012), whereas the abundance of $I$. glandulifera was estimated in terms of percentage cover. The nomenclature of vascular plants followed Mirek et al. (2002). In the space-for-time substitution approach, 35 plots with I. glandulifera cover of at least $50 \%$ (dominance of the species) were selected (hereafter, referred to as invaded plots) together with their paired control plots (hereafter, referred to as uninvaded plots). Analyses of diversity and vegetation composition in plots differing in the extent of $I$. glandulifera cover were performed for all 65 plots with I. glandulifera.

Data analysis

For each plot, we calculated the plant species richness $(S)$ as the number of vascular plant species per plot, Shannon diversity index $\left(H^{\prime}\right)$ as $H^{\prime}=-\sum p_{\mathrm{i}} \times \ln p_{\mathrm{i}}$, Simpson diversity index $(D)$ as $D=1-\sum p_{\mathrm{i}}^{2}$ and Pielou's evenness index $(J)$ as $J=H^{\prime} / \ln S$, where $p_{\mathrm{i}}$ is the proportion of species $i$ per plot (Hill 1973). For diversity calculations, Braun-Blanquet cover-abundance values $+, 1,2,3,4$ and 5 were transformed to $0.1,2.5,15.0,37.5,62.5$ and 87.5, respectively (Wildi 2010). I. glandulifera was not included in the data set used in the calculation of the diversity indices in order to evaluate the impact of the invader on the remaining species. To assess the impact of the invasion by $I$. glandulifera on resident vegetation, we compared invaded and uninvaded plots with respect to species richness, diversity and evenness measures. As statistical distributions of most of these diversity indices deviated from the normal distribution significance of 
differences in diversity measures between invaded and uninvaded plots, they were tested by the Wilcoxon signed-rank two-sided test. To examine the relationship between an increasing invader cover and the diversity of plant communities, we used boxplots with plots grouped in five I. glandulifera cover intervals: 0-20\%, 21-40\%, 41-60\%, 61-80\% and $81-100 \%$. Significance of differences in diversity measures between the intervals was tested by nonparametric multiple comparisons using rank-based Kruskal-Wallis test (Quinn and Keough 2011).

The potential impact of invasion by I. glandulifera on species composition was examined with non-metric multidimensional scaling (NMDS), which is an indirect multivariate ordination method. Non-metric multidimensional scaling based on the Bray-Curtis dissimilarity metric was performed for 35 pairs of invaded-uninvaded plots. In NMDS analysis, rare species occurring only in one or two plots (relevés) were excluded from subsequent analyses (Legendre and Legendre 2012). Also, I. glandulifera was excluded from this analysis because the aim of the analysis was to examine changes in the composition of the remaining species of resident vegetation. Species abundances were expressed in the original BraunBlanquet scale $(+, 1,2,3,4,5)$, with transformation of ' + ' into a value of 0.1 . This approach was applied to down-weight the influence of accidental high abundances of species on the ordination result. Non-metric multidimensional scaling analyses were performed using 50 random starting configurations, and we used accepted stress level close to or less than 0.2 to determine the dimensions of ordination (Paudel et al. 2017). To interpret the ecological shift in the species composition of invaded plots in relation to uninvaded plots, we superimposed on the ordination diagram mean Ellenberg's indicator values (EIVs) fitted post hoc to the NMDS ordination. Values of EIVs for light, soil nutrients, soil moisture and soil acidity (Ellenberg et al. 1992) were assigned to all species, if available, and their mean values for each plot were calculated. Only these EIV factors, which proved to be significant in the permutation test $(n=999)$ at the 0.05 significance level, were presented on the ordination diagram. The effect of the invasion on the species composition was assessed by comparison of the NMDS site scores of the pairs of invaded-uninvaded plots along the first and the second ordination axes, applying the Wilcoxon signed-rank test (Diekmann et al. 2016).
All statistical analyses were performed in $\mathrm{R}$ version 3.4.2 (R Core Team 2017). To compute diversity indices and perform NMDS analysis, the Community Ecology Package 'vegan' was used (Oksanen et al. 2017).

\section{Results}

Species richness, diversity and evenness

Invaded plots dominated by I. glandulifera had significantly reduced species richness and diversity compared to uninvaded control plots (Fig. 2). Uninvaded plots harboured an average of 19 species, while the invaded plots harboured 12 (Table 1), and this difference was highly significant $(V=14.5$, $p<0.001, n=35$ ). The weighted mean decline in the number of species in the pairs of invadeduninvaded plots was $27.2 \%$. Uninvaded plots most often had five to 10 species fewer compared to their uninvaded control plots (Fig. 2a). In total, 92 and 102 species were recorded in invaded and uninvaded plots, respectively (Table 1; Supplementary Table 1).

Vegetation with the dominance of I. glandulifera exhibited significantly lower values of Shannon diversity; for the invaded plots, the value of this index constituted $60.2 \%$ of the diversity of the uninvaded plots, and this difference was highly significant $(V=24, p<0.001, n=35)$ (Fig. 2b; Table 1). Also, Simpson diversity was reduced in the invaded vegetation; for the invaded plots, the value of this index constituted $73.7 \%$ of the diversity of the uninvaded plots, and this difference was also highly significant $(V=52, p<0.001, n=35)$ (Fig. 2c; Table 1). Similarly, Pielou's evenness index for the invaded plots constituted $70.0 \%$ of the index calculated for the uninvaded plots, and this difference proved to be significant $(V=59, \quad p<0.001, n=35) \quad$ (Fig. 2d; Table 1).

Along with an increase in the abundance of $I$. glandulifera in vegetation, changes in species richness and diversity were observed. Mean number of species per plot calculated for $20 \%$ intervals of I. glandulifera cover tended to decrease gradually with the increase in I. glandulifera cover; however, only plots with 81-100\% of I. glandulifera cover had significantly lower number of species as compared to groups of plots with lower I. glandulifera cover (Fig. 3a). The 

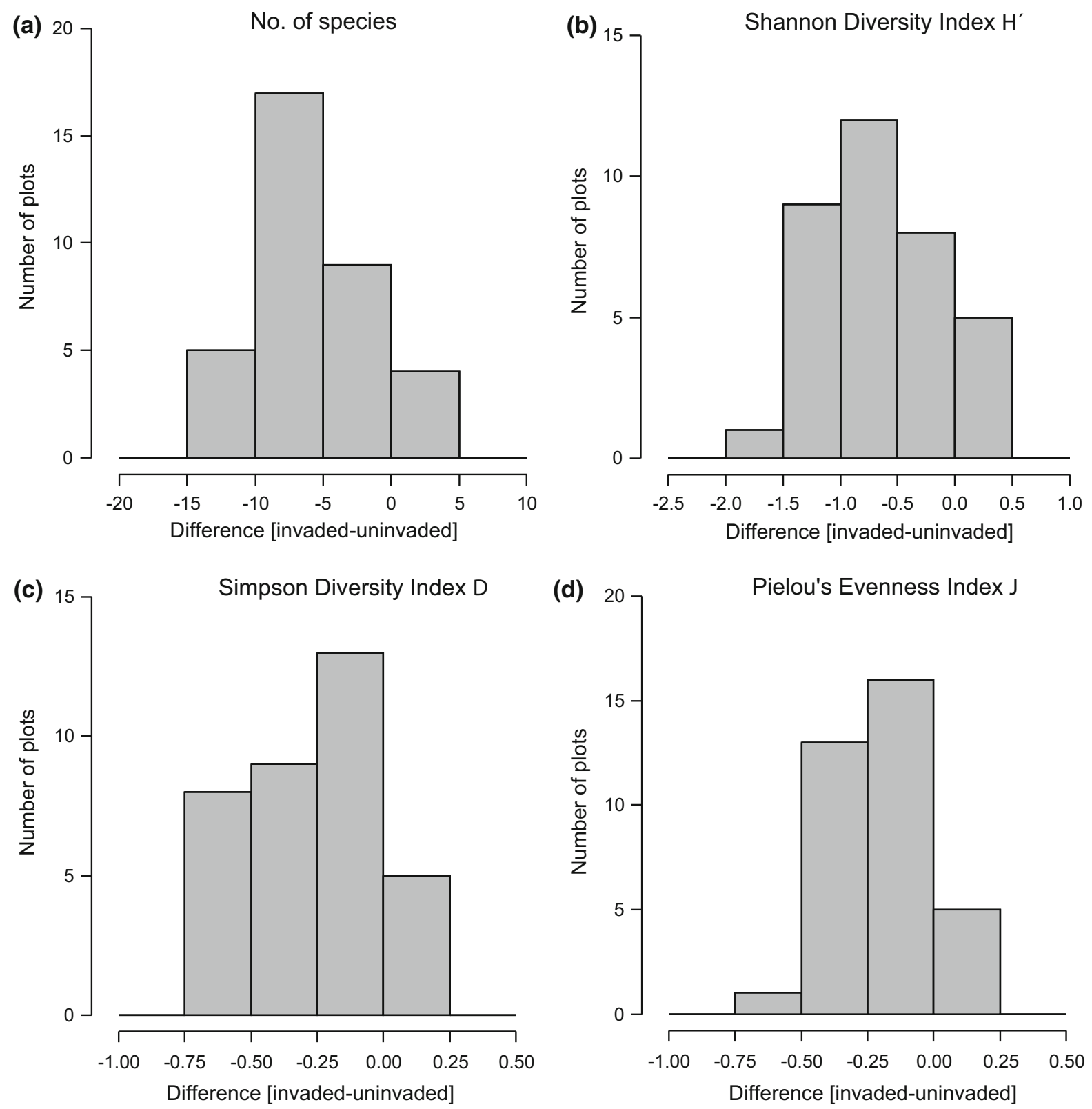

Fig. 2 Distributions of paired differences in diversity indices between invaded and uninvaded plots

three other investigated measures of species diversity decreased gradually their values in first four groups, up to $80 \%$ of I. glandulifera cover, but in the group of plots with the highest $I$. glandulifera cover exceeding $81 \%$ there were substantial significant reduction in their values observed (Fig. 3b, c, d).

\section{Species composition}

Increased I. glandulifera abundance caused changes in the floristic composition of invaded vegetation. NMDS revealed that the majority of invaded vegetation samples, as compared to uninvaded samples, were shifted along the first NMDS axis to the right, towards lower values of light EIV and higher values of nutrients EIV (Figs. 4, 5). This shift of NMDS scores 
Table 1 Number of species, Shannon diversity index $H^{\prime}$, Simpson diversity index $D$ and Pielou's evenness $J$, as recorded in the studied plots

\begin{tabular}{lllll}
\hline & Invaded plots & Uninvaded plots & Wilcoxon test & $P$ value \\
\hline $\begin{array}{l}\text { Total number of species } \\
\text { Plot species richness } S\end{array}$ & 92 & 102 & & \\
$\quad$ Median & 12 & 19 & $V=14.5$ & $p<0.001$ \\
Min & 7 & 7 & & \\
Max & 29 & 30 & $V=24$ & $p<0.001$ \\
Shannon diversity index $H^{\prime}$ & 1.03 & 1.71 & $V=52$ & $p<0.001$ \\
Simpson diversity index $D$ & 0.56 & 0.76 & $V=59$ & $p<0.001$ \\
Pielou's evenness index $J$ & 0.42 & 0.60 & & \\
\hline
\end{tabular}

along the first axis was statistically significant (median $=0.310, V=605, p<0.0001, n=35$ ). Along the second NMDS axis, no significant shift in scores of invaded samples, as compared to uninvaded, was observed (median $=-0.068, V=201, p=0.062$, $n=35$ ).

The most frequent species in the I. glanduliferadominated vegetation plots included Urtica dioica (frequency 86\%), Elymus repens and Poa trivialis (frequency of each species 66\%), Aegopodium podagraria (54\%) and Veronica chamaedrys (51\%). In the uninvaded plots, the most frequent species were Poa trivialis (83\%), Elymus repens (74\%), Veronica chamaedrys and Ranunculus repens (frequency of each species 66\%), Dactylis glomerata (60\%), Aegopodium podagraria and Urtica dioica (frequency of each species 57\%) and Phleum pratense (51\%) (Supplementary Table 1). The species most negatively affected by I. glandulifera invasion, which avoided vegetation dominated by the invader despite its presence in uninvaded control plots, included mainly fresh meadow species, such as Phleum pratense (34\% avoidance rate in pairs of invadeduninvaded plots), Agrostis capilaris, Ranunculus repens and Trisetum flavescens (each 23\% avoidance rate), Dactylis glomerata (20\% avoidance rate) and Agrostis stolonifera, Alchemilla sp., Cirsium arvense, Cirsium rivulare, Heracleum sphondylium, Poa trivialis and Rumex acetosa (each $17 \%$ avoidance rate). Distinctly more associated with the invaded compared to the uninvaded vegetation was Urtica dioica, a species which was present in $29 \%$ of the invaded vegetation samples despite simultaneous absence in their paired uninvaded controls.

\section{Discussion}

Our results suggest that invasion of vegetation by $I$. glandulifera may exert a negative impact on plant diversity of invaded vegetation, and this impact become very pronounced when I. glandulifera attains a cover above $80 \%$. All the investigated diversity measures, that is, species richness, Shannon and Simpson diversity indices and Pielou's evenness, had significantly lower values in I. glandulifera-dominated plots compared to uninvaded plots. As shown by the analysis of diversity measures, along with the increase in the cover of I. glandulifera, a very high abundance of the species expressed by its cover above $80 \%$ caused the reduction in diversity and evenness measures almost to zero. The exception was species richness; the number of species decreased gradually along with increase in I. glandulifera cover, and, in the heavily invaded vegetation in which I. glandulifera attained cover of $81-100 \%$, most often eight to 13 native plant species were still present.

Also, NMDS analysis of species composition revealed significant shifts in pairs of invaded-uninvaded plots. These shifts can be interpreted as the change in invaded vegetation composition, which resulted from the proportional increase in the more shade tolerant and nutrients demanding species, as indicated by the Ellenberg's indicator values fitted to the NMDS ordination. However, we must admit that, despite being statistically significant, the mean shifts along the first ordination axis had rather low absolute value, which can be explained by the fact that the species composition of the invaded plots predominantly represents only a reduced subset of uninvaded vegetation, which makes these plots similar in terms of species composition. 

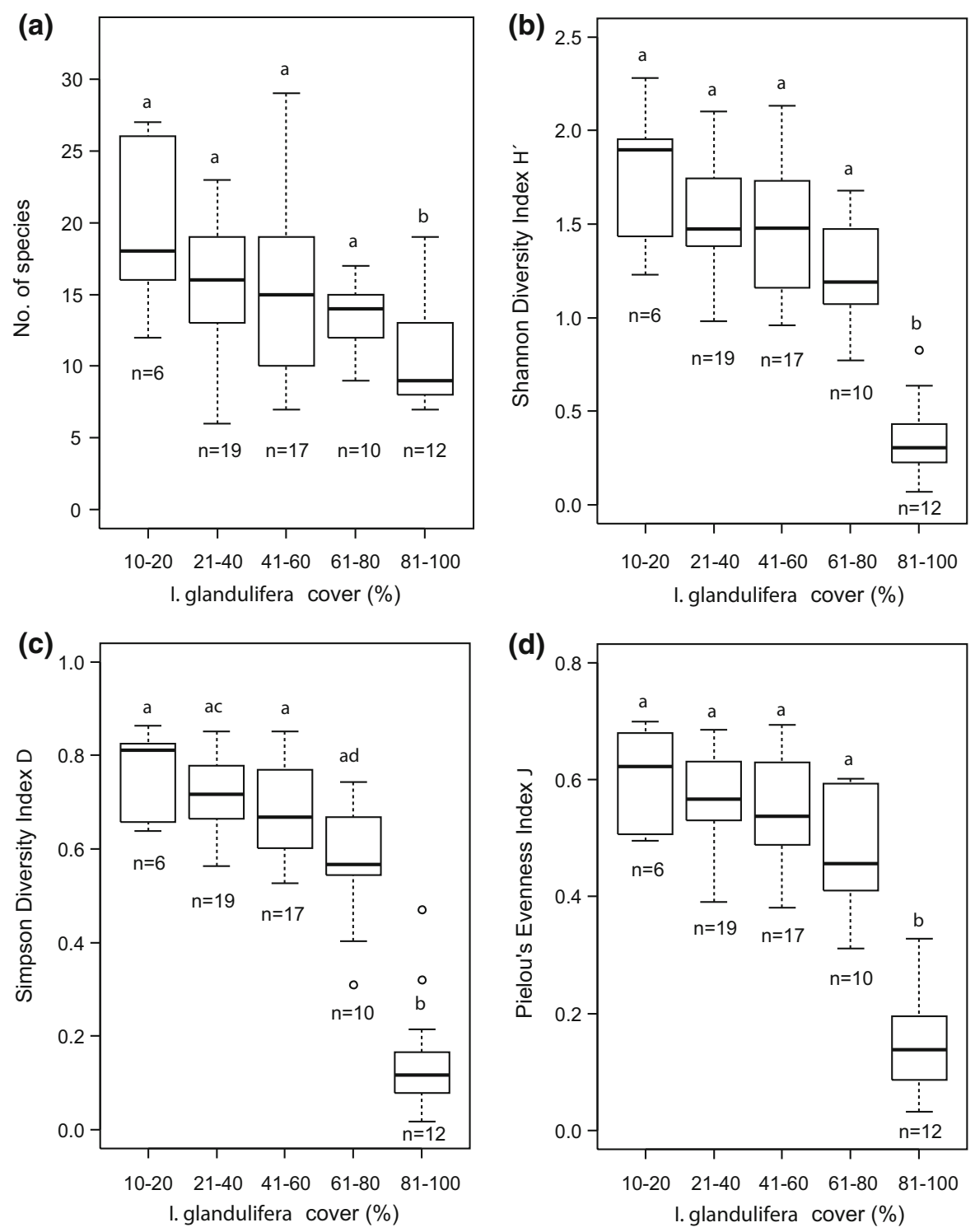

Fig. 3 Comparison of plot diversity indices along with the increase in I. glandulifera cover; a number of species, b Shannon diversity index $H^{\prime}$, c Simpson diversity index $D$, d Pielou's evenness $J$. Horizontal lines represent medians, boxes define

The decline in species richness of the invaded vegetation, as compared to the uninvaded, by as much as the $27 \%$ found in our study, agrees well with the results of Hulme and Bremner (2006) and Rusterholz et al. (2017), who found a $25 \%$ decrease in the number of species invaded by $I$. glandulifera in riparian and forest vegetation, respectively. The impact of the invader on resident vegetation in our study was stronger than the impact reported by Diekmann et al.

interquartile range IQR (25-75\%) and whiskers extend to IQR*1.5 range. Results of post hoc Kruskal-Wallis multiple comparisons indicated by letters above each boxplot

(2016); their survey of lowland habitats invaded by $I$. glandulifera found a $7.4 \%$ mean decline in species number per plot, whereas values of the Shannon diversity and evenness indices of the invaded plots constituted $73.6 \%$ and $75.0 \%$ of the uninvaded plots, respectively. Results of our study which suggest a considerable and significant impact of I. glandulifera on resident vegetation are contrary to the studies where no or a very slight impact of the invader was 


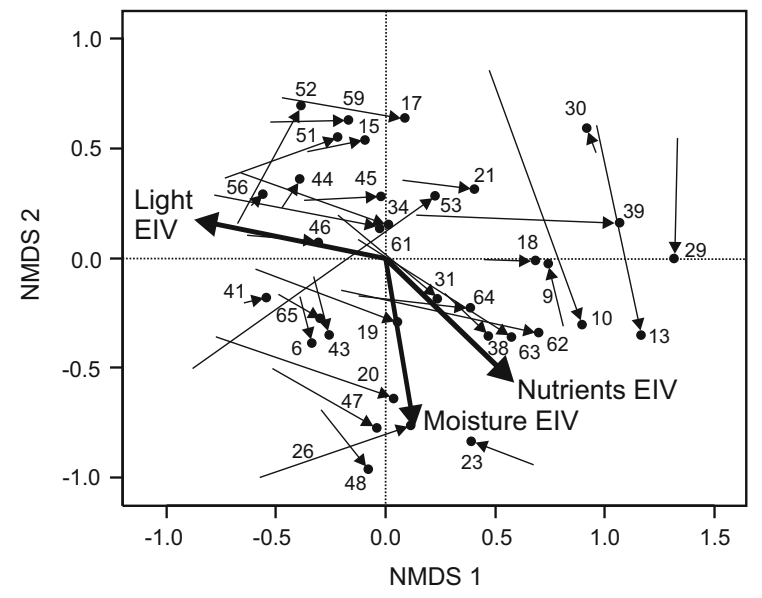

Fig. 4 Non-metric multidimensional scaling (NMDS) ordination of invaded and uninvaded plots based on vegetation composition, for three-dimensional NMDS (for clarity only axes 1 and 2 in ordination space are shown); arrows start at ordination scores of uninvaded plots and point towards paired invaded plots, indicating a shift in species composition. Numbers on the plot correspond to plot numbers in Supplementary Table 1

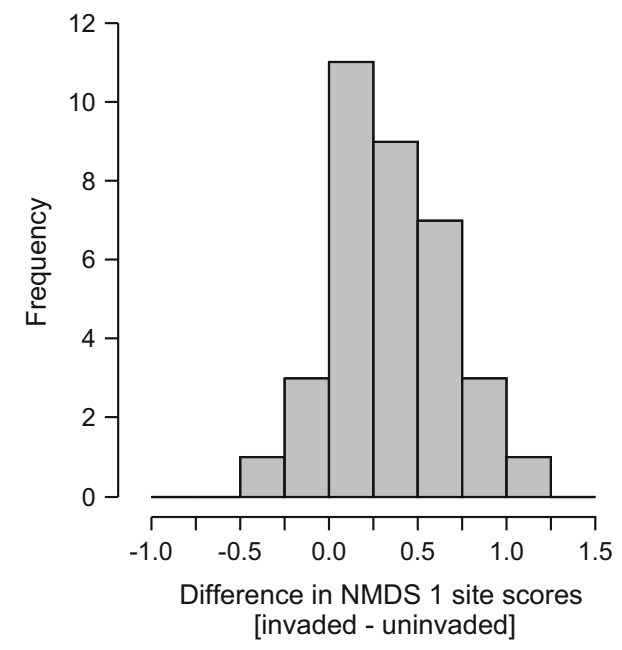

Fig. 5 Differences in NMDS ordination scores for pairs of invaded-uninvaded plots along the first ordination axis

found (Hejda and Pyšek 2006; Hejda et al. 2009; Künzi et al. 2015; Čuda et al. 2017b). This disparity may be explained by the fact that, in plant communities inhabited by a low number of species, $I$. glandulifera may not negatively impact species richness and diversity because this type of vegetation is often already dominated by native species, and the invader entering into such communities reduces the qualitative share of these dominant species by taking over their functions, as pointed out by Hejda and Pyšek (2006) and later also suggested by Čuda et al. (2017b). On the contrary, in species-rich vegetation, such as fresh meadows and communities related to fresh meadows inhabiting road embankments, I. glandulifera setting its dominance may suppress weak competitors and, thus, negatively impact plant diversity. A similar pattern was observed in the case of the invasion of species-rich sub-montane meadows by Heracleum mantegazzianum, where many competitively weak species were not present in the invaded sites (Pyšek and Pyšek 1995). The resident vegetation which we investigated was very rich in species, as compared, for example, with the investigated vegetation in studies by Hejda and Pyšek (2006), as well as Diekmann et al. (2016). The mean number of species in our study was 19 for $4 \mathrm{~m}^{2}$ in the uninvaded plots, whereas, in the riparian vegetation studied by Hejda and Pyšek (2006), the mean number of species was 9.2 for $16 \mathrm{~m}^{2}$ in the uninvaded plots, and, in the study of different invaded habitats by Diekmann et al. (2016), the mean species number was 10.5 for $10 \mathrm{~m}^{2}$ in the uninvaded plots. Therefore, as may be expected, the invader setting its dominance in species-rich communities will negatively impact diversity of the invaded vegetation.

It is worth mentioning that Hejda and Pyšek (2006) suggested earlier that the invasion by I. glandulifera into meadow communities composed of less competitive resident species than is the case of the invaded riparian habitats will possibly have a more profound effect on the invaded communities; this statement is supported by our results. With regard to lower impact or no impact of I. glandulifera on forest herb vegetation (Čuda et al. 2017b) as compared to open meadows, this can be partly because forest species are generally more shadow-tolerant, and perhaps many of them are capable of surviving under the canopy of dense stands of I. glandulifera. However, the results of another study on invasion of forest herb vegetation by I. glandulifera (Rusterholz et al. 2017) indicated significant negative effects of the species in deciduous forests.

The results of our study suggest the negative impact of I. glandulifera on species richness and diversity of invaded vegetation. However, some studies suggested that the overall impact of the species may not be very serious or detrimental. For example, Diekmann et al. pointed out that late phenological development of $I$. 
glandulifera means that mainly the late summer species are affected negatively, especially light-demanding ones, and that the species is not able to occupy a habitat over the entire growing season and over many years to such an extent that other plant species are permanently out-competed (Diekmann et al. 2016). Similarly, Čuda et al. (2017b) reported that non-riparian populations of I. glandulifera are much smaller than riparian ones, express strong yearto-year fluctuations of invader biomass and population size and persist for a shorter time. Moreover, they also found that the species did not markedly transform soil and litter characteristics in the forest ecosystem during the 3-year experiment. Therefore, it is possible that invasion by I. glandulifera does not necessarily cause detrimental changes in the vegetation which was investigated in this study at a plant community scale, despite the negative effects we found for the species based on the $4 \mathrm{~m}^{2}$ invaded plots. Populations of $I$. glandulifera, as an annual plant, show a high spatiotemporal dynamic (Čuda et al. 2017b) and may not exert a strong impact on resident vegetation over years. Also, we examined vegetation in late summer, in August and September, when the impact of $I$. glandulifera could be overestimated because this species was still in full vegetative and floral development, whereas, at that same time, many co-occurring species of the Molinio-Arrhenatheretea class, which develop earlier than I. glandulifera and have blossom peak in June and July, cease growth and begin to wither. It should be also acknowledged that in this study we analysed relationships between diversity indices in invaded and uninvaded plots, as well as in plots with different I. glandulifera cover. However, this study cannot render definitive statement as to the causes of the observed pattern of diversity and to what degree the observed diversity pattern was driven by the invasive species or some other, unmeasured factors. Further studies on permanent plots including the entire vegetation period and conducted for several years, as was done, for example, in the study by Rusterholz et al. (2016), would contribute to enhanced assessment of the overall impact of the species on the resident vegetation.

In conclusion, the results of this study suggest that, in species-rich tall herb communities, invasion by $I$. glandulifera causes a considerable change in plant species richness, diversity and evenness. Diversity indices of the invaded plant communities decrease gradually along with the increase in I. glandulifera cover up to $80 \%$, but after exceeding a $80 \%$ cover, this species dramatically reduce the diversity of the invaded vegetation. It is worth mentioning that we found tall, normally developed and flowering $I$. glandulifera plants, forming dense and vital populations on sites reaching to maximum elevations of up to $1,100 \mathrm{~m}$ a.s.l., and some were situated within or at the border of the Tatra National Park. Taking into account that, in its primary range, this species grows at high elevations up to 4,300 m a.s.l. (Adamowski 2008), as well as predicted future climate change scenarios (e.g. Theurillat and Guisan 2001), it is possible that $I$. glandulifera will continue expansion at higher Tatra Mountains elevations, where many rare and vulnerable mountain species may be threatened. Therefore, regular monitoring of the invader's presence in the Tatra National Park is recommended, and, when needed, eradication actions, which have been found to be highly effective in other Central European national parks (Schiffleithner and Essl 2016), should be undertaken to prevent the invader's spread in the protected area.

\section{Compliance with ethical standards}

Conflict of interest The authors declare that they have no conflict of interest.

Open Access This article is distributed under the terms of the Creative Commons Attribution 4.0 International License (http:// creativecommons.org/licenses/by/4.0/), which permits unrestricted use, distribution, and reproduction in any medium, provided you give appropriate credit to the original author(s) and the source, provide a link to the Creative Commons license, and indicate if changes were made.

\section{References}

Adamowski W (2008) Balsams on the offensive: the role of planting in the invasion of Impatiens species. In: TokarskaGuzik B, Brock JH, Brundu G, Child L, Daehler CC, Pyšek $\mathrm{P}$ (eds) Plant invasions: human perception, ecological impacts and management. Backhuys Publishers, Leiden, pp 57-70

Andrews M, Maule HG, Hodge S, Cherrill A, Raven JA (2009) Seed dormancy, nitrogen nutrition and shade acclimation of Impatiens glandulifera: implications for successful invasion of deciduous woodland. Plant Ecol Divers 2:145-153

Beerling DJ, Perrins JM (1993) Biological flora of the British Isles: Impatiens glandulifera Royle (Impatiens Roylei Walp.). J Ecol 81:367-382 
Bottollier-Curtet M, Planty-Tabacchi A-M, Tabacchi E (2013) Competition between young exotic invasive and native dominant plant species: implications for invasions within riparian areas. J Veg Sci 24:1033-1042

Clements DR, Feenstra KR, Jones K, Staniforth R (2008) The biology of invasive alien plants in Canada. 9. Impatiens glandulifera Royle. Can J Plant Sci 88:403-417

Čuda J, Skálová H, Janovský Z, Pyšek P (2014) Habitat requirements, short-term population dynamics and coexistence of native and invasive Impatiens species: a field study. Biol Invasions 16:177-190

Čuda J, Skálová H, Janovský Z, Pyšek P (2015) Competition between native and invasive Impatiens species: the roles of environmental factors, population density and life stage. AoB Plants 7:plv033. https://doi.org/10.1093/aobpla/ plv033

Čuda J, Rumlerová Z, Brůna J, Skálová H, Pyšek P (2017a) Floods affect the abundance of invasive Impatiens glandulifera and its spread from river corridors. Diversity Distrib 23:342-354

Čuda J, Vítková M, Albrechtová M, Guo W-Y, Barney JN, Pyšek P (2017b) Invasive herb Impatiens glandulifera has minimal impact on multiple components of temperate forest ecosystem function. Biol Invasions 19:3051-3066

Dainese M, Kühn I, Bragazza L (2014) Alien plant species distribution in the European Alps: influence of species' climatic requirements. Biol Invasions 16:815-831

Diekmann M, Effertz H, Baranowski M, Dupré C (2016) Weak effects on plant diversity of two invasive Impatiens species. Plant Ecol 217:1503-1514

Ellenberg H, Weber HE, Düll R, Wirth V, Werner W, Paulissen D (1992) Indicator values of plants in Central Europe. 2nd ed. Scripta Geobot 18:1-257

Fried G, Laitung B, Pierre C, Chagué N, Panetta FD (2014) Impact of invasive plants in Mediterranean habitats: disentangling the effects of characteristics of invaders and recipient communities. Biol Invasions 16:1639-1658

Gaertner M, Biggs R, Te Beest M, Hui C, Molofsky J, Richardson DM (2014) Invasive plants as drivers of regime shifts: identifying high-priority invaders that alter feedback relationships. Diversity Distrib 20:733-744

Gruntman M, Pehl AK, Joshi S, Tielbörger K (2014) Competitive dominance of the invasive plant Impatiens glandulifera: using competitive effect and response with a vigorous neighbour. Biol Invasions 16:141-151

Gurevitch J, Padilla DK (2004) Are invasive species a major cause of extinctions? Trends Ecol Evol 19:470-474

Hejda M (2009) Species accounts of 100 of the most invasive alien species in Europe: Impatiens glandulifera Royle, Himalayan balsam (Balsaminaceae, Magnoliophyta). In: DAISIE, Handbook of alien species in Europe. Invading nature: Springer series in invasion ecology 3. Springer, New York, p 351

Hejda M (2013) Do species of invaded communities differ in their vulnerability to being eliminated by the dominant alien plants? Biol Invasions 15:1989-1999

Hejda M, Pyšek P (2006) What is the impact of Impatiens glandulifera on species diversity of invaded riparian vegetation? Biol Conserv 132:143-152
Hejda M, Pyšek P, Jarošík V (2009) Impact of invasive plants on the species richness, diversity and composition of invaded communities. J Ecol 97:393-403

Hejda M, Štajerová K, Pyšek P (2017) Dominance has a biogeographical component: do plants tend to exert stronger impacts in their invaded rather than native range? J Biogeogr 44:18-27

Hill MO (1973) Diversity and evenness: a unifying notation and its consequences. Ecology 54:427-473

Hulme PE, Bremner ET (2006) Assessing the impact of Impatiens glandulifera on riparian habitats: partitioning diversity components following species removal. J Appl Ecol 43:43-50

Kent M (2012) Vegetation description and data analysis. A practical approach. John Wiley \& Sons. Ltd., WileyBlackwell

Kiełtyk P (2014) Distribution pattern of the invasive alien plant Bunias orientalis L. in Rów Podtatrzański trench, north of the Tatra Mts. Poland. Biologia 69:323-331

Kłapowa M (1993) Klimat Zakopanego. In: Mirek Z, PiękośMirkowa H (eds) Przyroda Kotliny Zakopiańskiej. Series Tatry i Podtatrze vol. 2. Tatrzański Park Narodowy, Kraków, Zakopane, pp 31-47

Kostrakiewicz-Gierałt K, Zając M (2014) The influence of habitat conditions on the performance of two invasive, annuals-Impatiens glandulifera and Bidens frondosa. Biologia 69:449-462

Künzi Y, Prati D, Fischer M, Boch S (2015) Reduction of native diversity by invasive plants depends on habitat conditions. Am J Plant Sci 6:2718-2733

Lazzaro L, Giuliani C, Benesperi R, Calamassi R, Foggi B (2015) Plant species loss and community nestedness after leguminous tree Acacia pycnathea invasion in a Mediterranean ecosystem. Folia Geobot 50:229-238

Legendre P, Legendre L (2012) Numerical ecology, 3rd edn. Elsevier Science B.V, Amsterdam

Levine JM, Vilà M, D'Antonio CM, Dukes JS, Grigulis K, Lavorel S (2003) Mechanisms underlying the impacts of exotic plant invasions. Proc R Soc Lond B 270:775-781

Loydi A, Donath TW, Eckstein RL, Otte A (2015) Non-native species litter reduces germination and growth of resident forbs and grasses: allelopathic, osmotic or mechanical effects? Biol Invasions 17:581-595

Mack RN, Simberloff D, Lonsdale WM, Evans H, Clout M, Bazzaz FA (2000) Biotic invasions: causes, epidemiology, global consequences, and control. Ecol Appl 10:689-710

Mirek Z, Piękoś-Mirkowa H, Zając A, Zając M, Bernacki L, Cieślak E, Głowacki Z, Leda M, Mitka J, Paśnik A, Paul W, Ronikier M, Rostański K, Szeląg Z, Wójcicki JJ, Zalewska-Gałosz J, Zieliński J, Zukowski W (2002) Flowering plants and pteridophytes of Poland. A checklist. W. Szafer Institute of Botany, Polish Academy of Sciences, Kraków

Oksanen J, Blanchet FG, Friendly M, Kindt R, Legendre P, McGlinn D, Minchin PR, O'Hara RB, Simpson GL, Solymos P, Stevens MHH, Szoecs E, Wagner H (2017) vegan: Community Ecology Package. R package (version 2.4-4). https://CRAN.R-project.org/package=vegan

Parker IM, Simberloff D, Lonsdale WM, Goodell K, Wonham M, Kareiva PM, Williamson MH, Von Holle B, Moyle PB, Byers JE, Goldwasser L (1999) Impact: toward a 
framework for understanding the ecological effects of invaders. Biol Invasions 1:3-19

Paudel S, Benavides JC, MacDonald B, Longcore T, Wilson GWT, Loss SR (2017) Determinants of native and nonnative plant community structure on an oceanic island. Ecosphere 8(9):e01927. https://doi.org/10.1002/ecs2.1927

Perrins J, Fitter A, Williamson M (1993) Population biology and rates of invasion of three introduced Impatiens species in the British Isles. J Biogeogr 20:33-44

Polunin O, Stainton A (1984) Flowers of the Himalaya. Oxford UP, Oxford

Protopopova VV, Shevera MV, Orlov OO, Panchenko SM (2015) The transformer species of the Ukrainian Polissya. Biodiv Res Conserv 39:7-18

Pyšek P, Prach K (1995) Invasion dynamics of Impatiens glandulifera - a century of spreading reconstructed. Biol Conserv 74:41-48

Pyšek P, Pyšek A (1995) Invasion by Heracleum mantegazzianum in different habitats in the Czech Republic. J Veg Sci 6:711-718

Pyšek P, Chytrý M, Pergl J, Sádlo J, Wild J (2012) Plant invasions in the Czech Republic: current state, introduction dynamics, invasive species and invaded habitats. Preslia 84:575-629

Quinn GP, Keough MJ (2011) Experimental design and data analysis for biologists. Cambridge UP, Cambridge

R Core Team (2017) R: a language and environment for statistical computing. R Foundation for Statistical Computing, Vienna, Austria. https://www.R-project.org/

Richardson DM, Pyšek P (2006) Plant invasions: merging the concepts of species invasiveness and community invasibility. Prog Phys Geog 30:409-431

Ruckli R, Hesse K, Glauser G, Rusterholz H-P, Baur B (2014) Inhibitory potential of naphthoquinones leached from leaves and exuded from roots of the invasive plant Impatiens glandulifera. J Chem Ecol 40:371-378

Rusterholz H-P, Küng J, Baur B (2017) Experimental evidence for a delayed response of the above-ground vegetation and the seed bank to the invasion of an annual exotic plant in deciduous forests. Basic Appl Ecol 20:19-30

Sakai AK, Allendorf FW, Holt JS, Lodge DM, Molofsky J, With KA, Baughman S, Cabin RJ, Cohen JE, Ellstrand NC, McCauley DE, O’Neil P, Parker IM, Thompson JN, Weller
SG (2001) The population biology of invasive species. Annu Rev Ecol Evol Syst 32:305-332

Schiffleithner V, Essl F (2016) Is it worth the effort? Spread and management success of invasive alien plant species in a Central European National Park. NeoBiota 31:43-61

Sharma BM, Jamwal PS (1988) Flora of upper liddar valleys of Kashmir Himalaya. Scientific Publishers, Jodhpur

Tanner RA, Jin L, Shaw R, Murphy ST, Gange AC (2014) An ecological comparison of Impatiens glandulifera Royle in the native and introduced range. Plant Ecol 215:833-843

Theurillat J-P, Guisan A (2001) Potential impact of climate change on vegetation in the European Alps: a review. Clim Change 50:77-109

Tokarska-Guzik B (2005) The establishment and spread of alien plant species (kenophytes) in the flora of Poland. Wydawnictwo Uniwersytetu Śląskiego, Katowice

Vilà M, Tessier M, Suehs CM, Brundu G, Carta L, Galanidis A, Lambdon P, Manca M, Médail F, Moragues E, Travaset A, Troumbis AY, Hulme PE (2006) Local and regional assessments of the impacts of plant invaders on vegetation structure and soil properties of Mediterranean islands. J Biogeogr 33:853-861

Wagner V, Chytrý M, Jiménez-Alfaro B, Pergl J, Hennekens S, Biurrun I, Knollová I, Berg Ch, Vassilev K, Rodwell JS, Škvorc Ž, Jandt U, Ewald J, Jansen F, Tsiripidis I, BottaDukát Z, Casella L, Attorre F, Rašomavičius V, Ćušterevska R, Schaminée JHJ, Brunet J, Lenoir J, Svenning J-Ch, Kącki Z, Petrášová-Šibíková M, Šilc U, García-Mijangos I, Campos JA, Fernández-González F, Wohlgemuth T, Onyshchenko V, Pyšek P (2017) Alien plant invasions in European woodlands. Divers Distrib 23:969-981

Weber E (2003) Invasive plant species of the world. A reference guide to environmental weeds. CABI Publishing, Wallingford

Wildi O (2010) Data analysis in vegetation ecology. Wiley, Wiley-Blackwell, West Sussex

Williamson M, Pyšek P, Jarošík V, Prach K (2005) On the rates and patterns of spread of alien plants in the Czech Republic, Britain, and Ireland. Ecoscience 12:424-433

Zając A, Zając M (eds) (2001) Distribution atlas of vascular plants in Poland. Laboratory of Computer Chorology. Institute of Botany, Jagiellonian University, Kraków 